UNIVERSIDADE DE BRASÍLIA

\title{
A ESQUERDA NA AMÉRICA DO SUL: ENCONTROS E DESENCONTROS
}

\author{
POR \\ LÍSIA GUSMÃO CARVALHO
}

Brasília, março de 2008 
Universidade de Brasília

Instituto de Relações Internacionais

IX Curso de Especialização em Relações Internacionais

A ESQUERDA NA AMÉRICA DO SUL: ENCONTROS E DESENCONTROS

POR

LÍSIA GUSMÃO CARVALHO

758728

ORIENTADORA MARIA HELENA DE CASTRO SANTOS 
1 - DUAS ESQUERDAS

1.2 - DEMOCRATAS E ANTIDEMOCRATAS

1.3 - INSERÇÃO INTERNACIONAL

2 - RECURSOS DE PODER

2.2 - PETRÓLEO VERSUS ETANOL

3 - CONFLITOS

3.1 - MERCOSUL VERSUS ALBA

3.2 - INTEGRAÇÃO ENERGÉTICA 26

3.3 - INTEGRAÇÃO FINANCEIRA

CONCLUSÃO 


\section{INTRODUÇÃO}

Em princípio, pode parecer simplista reduzir o mapa da esquerda da América do Sul à divisão entre moderados e radicais, mas tampouco seria adequado enquadrar seus líderes em uma única corrente. O giro sul-americano à esquerda não é homogêneo, nem mesmo coeso. Há duas esquerdas, com recursos de poder e modelos de integração conflitantes. O que este trabalho procura analisar é a disputa pela liderança da América do Sul e o impacto dos contenciosos sobre os projetos de integração regional.

Em essência, os anos 2000 marcam o fim do pensamento único e da hegemonia neoliberal e o início de um período de maior pluralidade, em que se encontram diferentes formas democráticas de lidar com as conseqüências da liberalização econômica. Apesar de heterogêneo, o movimento político mais recente tem em comum o fim do pensamento único e da hegemonia neoliberal, e o início de um período de maior pluralidade, em que se encontram diferentes formas democráticas de lidar com as conseqüências da liberalização econômica (Coutinho, 2006b).

Cada corrente desta onda esquerdista encontra inspiração nos presidentes do Brasil, Luiz Inácio Lula da Silva, e da Venezuela, Hugo Chávez. Não é fácil defini-los, tarefa que deixo para os escritores.

Por ocasião da reeleição de Lula, em 2006, Luís Fernando Veríssimo escreveu:

"O grande valor político de Lula é o que ele simboliza na pantonímia, o seu valor metafórico. Seu personagem não é significativo só pelas razões sentimentais óbvias - ex-retirante, cara que veio de baixo e venceu etc. -, mas pela didática comparação com outras figuras atuais ou tradicionais do nosso teatro eleitoral. Sua origem contrasta com uma história feita até agora de cima para baixo, com escassa participação popular, $e$ com a rotina histórica da espoliação do Brasil pela sua própria elite. Seus problemas com a sintaxe e a gramática o contrapõem às gerações de doutores que construíram a sociedade mais desigual do mundo sem cometer nenhum erro de concordância. E se nada disso é muito relevante na vida real, leiase econômica do país, não deixa de ser divertido no nível da caricatura mais primária, da pantonímia da criança - ver o desespero da nobreza inconformada com a evidência de que o barbudo mal nascido vai ficar, outra vez, com a princesa. Falta dizer que, sem escapar da submissão às regras do capital financeiro, este 
governo conseguiu começar um processo de transferência de renda, falho e insuficiente, mas inédito no país" (O Globo, 2006).

Duas semanas após a posse de Chávez, analisou García Márquez:

"Enquanto se afastava entre sua escolta de militares condecorados e amigos de primeira hora, fui tomado pela estranha sensação de que havia viajado e conversado com gosto com dois homens opostos. Um a quem a sorte obstinada oferecia a oportunidade de salvar seu país. E o outro, um ilusionista, que podia passar para a história como um déspota a mais" (Le Monde Diplomatique Brasil, 2000).

Desde que assumiu o poder na Venezuela, Chávez passou a ser considerado como um dos mais importantes líderes da esquerda da América Latina, talvez quem substituísse Fidel Castro. Do pensamento de Simon Bolívar, aproveita, sobretudo, três elementos: a luta anti-colonial, a hostilidade aos Estados Unidos e a defesa da integração latino-americana. Na retórica chavista combativa, essas características tornam-se a base para um discurso antiimperialista (Valente e Santoro, 2006).

A liderança da América do Sul, que naturalmente caberia ao Brasil por seus atributos geopolíticos, passou a ser almejada por Chávez. Contudo, a Venezuela, embora estrategicamente importante por causa do petróleo, não representa uma ameaça real ao papel de estabilização desempenhado agora pelo governo de Lula. Obviamente, Chávez deseja uma Venezuela mais ativa no cenário internacional, com voz e autonomia, o que difere da posição de liderança.

O que este trabalho procura demonstrar é que uma disputa - ideológica, política e econômica - é, de fato, sentida nos âmbitos nacionais, nos alinhamentos regionais e nas relações internacionais, nos processos de integração e nos acordos bilaterais, gerando encontros e desencontros nas próprias teias da esquerda. Mas este trabalho sustenta que não há, no horizonte, um rompimento, como se em jogo estivesse a alma da América do Sul. 
1 - DUAS ESQUERDAS

A esquerda sul-americana no início do século XXI é heterogênea, amparada em duas correntes que se aproximam e se distanciam segundo o movimento no tabuleiro do xadrez político. Há laços que as unem, porém, são evidentes as divergências em conteúdo, estilo, forma e tom.

A corrente considerada moderada é liderada pelo presidente do Brasil, Luiz Inácio Lula da Silva. Outra, radical, menos institucionalizada, é encarnada pelo presidente da Venezuela, Hugo Chávez. Os dois compartilham algumas características. Ambos foram eleitos com um discurso de contestação das medidas liberais e o compromisso firme com a diminuição da pobreza e da desigualdade. Também os une a marca incontestável, em seus governos, de elementos nacionalistas e de uma identidade sul-americana muito forte. E, embora procurem revisar o passado liberal, não romperam com os fundamentos econômicos herdados de seus antecessores (Lima e Coutinho, 2006).

Segundo Coutinho (2007), não há hoje uma receita de bolo, uma fórmula préfabricada e generalizante, e muito menos um conjunto de idéias pró-mercado que, ao ser obedecido pelos governos, produz automaticamente o desenvolvimento da América do Sul. Em vez disso, existem hoje na região grandes ambigüidades. Um governo pode, ao mesmo tempo, hostilizar politicamente os Estados Unidos e preservar as relações econômicas com este país. Buscar a integração sul-americana quando também negocia um acordo preferencial com outras nações fora da região. Manifestar-se contra a privatização, mas reconhecer a importância dos investimentos externos. Existem restrições de ordem econômica e reivindicações de natureza social de difícil conciliação e das quais os governos não têm como escapar, em um jogo de permanente tensão.

A esquerda considerada moderada deixou para trás um certo romantismo e assumiu valores democráticos e o apego à estabilidade econômica como elementos sine qua non de seu projeto - um reconhecimento de que, manejada com irresponsabilidade, a macroeconomia é capaz de produzir amargas vinganças.

Essa corrente, que governa o Brasil, o Chile e o Uruguai - a Argentina pode ser considerada uma “categoria em si mesma”, como definiu Pérez Llana (2007) - marcha por um caminho de reformismo avançado, maduro, combinando sensibilidade social com a compreensão de que as transformações na sociedade passam pelo desenvolvimento econômico e pelo fortalecimento e aprofundamento da democracia. Contudo, não escapa da 
tensão entre o compromisso com as idéias e o sentido pragmático que implica percepção realista do mundo interdependente.

Coutinho (2007) observa que há um pragmatismo de esquerda presente hoje na América do Sul em diferentes gradações e matizes. Segundo ele, no pragmatismo, uma política não é boa nem ruim em si mesma, mas naquilo que ela pode gerar efetivamente de positivo ou negativo para o país. Isso significa, acrescenta, que tais governos são capazes de tomar medidas liberais ou tidas como de direita em certas circunstâncias, e assumir posições mais genuinamente de esquerda em outras.

A esquerda moderada trilhou o caminho do poder nos países do Cone Sul, onde o sistema partidário é capaz de oferecer um canal mais institucionalizado de expressão dos conflitos, de incluir novos atores políticos e sociais e, conseqüentemente, de intermediar suas relações com o poder público, normalizando, assim, a vida democrática (Coutinho, 2006).

Lula assumiu o governo brasileiro sob o ataque especulativo de uma crise financeira internacional, mas não em meio a uma crise institucional. Não havia (e não há), no Brasil, um debate sobre a legitimidade das instituições políticas. Porém, quando o sistema não está funcionando bem, é preciso modificá-lo, admitiu o mega-investidor George Soros, observando que é “inaceitável” a idéia de que a "democracia somente é boa, desde que o eleito seja o candidato dos mercados”. E o que ficou claro com a eleição de Lula em 2002 é que havia desejo de mudança.

Mas, ao contrário, a corrente esquerdista que ecoa nos Andes, sobretudo na Bolívia, Equador e Venezuela, é agressiva, anti-sistêmica, fruto da implosão do sistema partidário, que colocou o Estado em xeque. Líder dessa vertente, Chávez recusou a sensatez e abraçou uma retórica combativa. A estabilidade política, econômica e social venezuelana, apoiada em um sistema bipartidário excludente, formado a partir do chamado Pacto de Punto Fijo, já apresentava as primeiras fissuras desde 1989, quando, apenas alguns dias após a ascenção de Carlos Andrés Pérez, da Acción Democrática, à presidência, o povo saiu às ruas para expressar repúdio ao pacote econômico de cunho neoliberal nos moldes exigidos pelo Fundo Monetário Internacional (FMI). A crise financeira do início dos anos 80 produziu uma crescente deterioração dos padrões de vida da classe média e aumento da pobreza, acentuados também pela queda do preço do petróleo - principal commodity e esteio fiscal do país (Santana e Kasahara, 2007).

A violenta série de distúrbios e saques provocou quase 300 mortes e o ambiente de descontentamento permitiu que o tenente-coronel Hugo Chávez tentasse um golpe de Estado em 3 de fevereiro de 1992. O golpe fracassou, mas Chávez tornou-se tão 
popular que se elegeu presidente da Venezuela em 1998 com a promessa de uma "revolución pacífica y democrática”.

Em meio a uma grave crise política, Chávez teve que implementar um ajuste econômico tão forte, que derrubou o valor do bolívar. Caracas transformou-se em um centro de manifestações populares e abriu-se caminho para uma tentativa de golpe contra Chávez, levado a cabo pelo ministro da Defesa, o chefe do Estado Maior do Exército da Venezuela e o chefe da segurança do Palácio Miraflores. Mas o golpe de Estado encorajado pelos Estados Unidos fracassou em virtude da oposição popular e do repúdio dos demais países da América do Sul. E o outsider Hugo Chávez permanece no poder.

\section{1 - POPULISTAS}

Hugo Chávez, líder dos radicais da esquerda sul-americana, estabeleceu uma clara relação líder-massa, típica do populismo, que tem como marca a divisão da sociedade entre o povo e seus "opressores”, o enfraquecimento de instituições intermediárias, como partidos políticos e Parlamento, e o constante reforço da noção de soberania popular e do conflito entre poderosos e excluídos.

Segundo Panizza (2006), o populismo tem mais chances em contextos sóciopolíticos em que as reformas de mercado produziram graves crises políticas, como na Venezuela, ou aprofundaram ainda mais divisões históricas de raízes étnicas, regionais ou sócio-econômicas, como na Bolívia.

Por sua vez, Lula, líder dos moderados, embora tenha ameaçado recorrer ao discurso de conspiração das elites na crise política de 2005, não parece atuar para a divisão da sociedade brasileira e muito menos à margem das instituições intermediárias. Além disso, adota uma política econômica austera. Uma das premissas do populismo, ao contrário, é a adoção de políticas macroeconômicas expansivas e de controle do mercado com propósitos distributivos para combater a desigualdade, sem o devido cuidado com o déficit fiscal e os equilíbrios econômicos.

Coutinho (2007) nos explica que o neoliberalismo, geralmente elitista e avesso ao Estado, tem mais apego à estabilidade monetária do que ao crescimento econômico com inclusão social, enquanto o populismo preocupa-se menos com as taxas inflacionárias e com o equilíbrio das contas públicas, nelas incluído o endividamento.

O governo de Lula, assim como os de Michelle Bachelet, no Chile, e de Tabaré Vásquez, no Uruguai, ajustaram suas estratégias para competir no sistema partidário e 
assumiram as regras e restrições, políticas ou econômicas, da democracia liberal e da economia de mercado. No seu sentido mais amplo e em contraste com a esquerda revolucionária, os moderados são identificados pela tentativa de reforma gradual do capitalismo para incorporar princípios de igualdade e de justiça social, ou seja, uma vez no poder, tentam combinar políticas pró-mercado com políticas sociais que atenuem seus efeitos sobre os mais excluídos.

Um dos contrastes entre moderados e radicais reside na força e legitimidade das instituições políticas e nos efeitos das reformas de mercado sobre a sociedade. A maior estabilidade política e institucional da esquerda moderada não pode ser separada da estabilidade econômica alcançada nos últimos anos e dos benefícios para setores importantes da população.

\section{2 - DEMOCRATAS E ANTIDEMOCRATAS}

A nova esquerda sul-americana não apenas aceitou o voto popular como instrumento de ascenção ao poder, mas incorporou a democracia representativa como regime de governo e padrão de relacionamento institucional. No entanto, o pleno reconhecimento da pluralidade social e do pluralismo político tem diferentes gradações.

De acordo com a Freedom House, organização não-governamental que trabalha em defesa da democracia, em termos de garantia dos direitos políticos, Chile e Uruguai são os países mais avançados da América do Sul, seguidos de Argentina, Brasil e Peru, onde a corrupção, a violência, e a influência militar ou estrangeira comprometem a qualidade do sistema político. Além dos fatores acima mencionados, características de uma guerra civil contribuem para o enfraquecimento dos direitos políticos na Bolívia, Colômbia, Equador e Paraguai. A Venezuela, por sua vez, tem o pior desempenho.

Em relação à garantia das liberdades civis, a Freedom House coloca no topo do ranking Argentina, Chile e Uruguai, países onde a população tem assegurada a liberdade de expressão, de associação, educação e religião, a atividade econômica é considerada livre e o estado de direito, consolidado. O Brasil vem em seguida, com deficiências em alguns aspectos, mas, ainda assim, é considerado relativamente livre.

Contudo, o terrorismo político e o nível de opressão na Bolívia, Colômbia, Equador, Paraguai e Peru ameaçam as liberdades civis. E, por estes mesmos fatores, a Venezuela é considerado o país da América do Sul onde é verificado maior nível de cerceamento das liberdades individuais. 
Analisado o grau de liberdade do sistema político e dos direitos civis, a Freedom House classifica como países livres, com os seguintes scores, Argentina (2), Brasil (2), Chile (1), Peru (2,5) e Uruguai (1), enquanto Bolívia (3), Colômbia (3), Equador (3), Paraguai (3) e Venezuela (4) foram apontados como parcialmente livres.

A Freedom House considera, em seu método, países livres aqueles com score entre 1.0 e 2.5, parcialmente livres os com score entre 3.0 e 5.0, e não livres os países com score entre 5.5 e 7.0 .

O exercício do governo na Venezuela é ambivalente. A prática cada vez mais dura do poder reflete-se no controle absoluto do presidente sobre as instituições do Estado, na tendência à supressão dos espaços democráticos e nas pressões constantes sobre os meios de comunicação. A formação militar, por sua própria natureza, é pouco democrática, fincada na força da disciplina vertical, na subordinação escalonada e em procedimentos não deliberativos. Não é o governo de Chávez uma ditadura, mas a democracia representativa deixa a desejar.

A democracia representativa caracteriza-se pela alta institucionalização das práticas democráticas, respeito à formação da vontade política por meio da regra da maioria, funcionamento do mecanismo de accountability - vertical e horizontal - ou de prestação de contas, incorporação dos grupos organizados e representativos de interesses sociais na definição e discussão da agenda política, e institucionalização dos mecanismos eleitorais que exprimem os desejos da maioria e da minoria na eleição de seus representantes.

O contraponto prevalecente na América do Sul é caracterizado pelo que Guilhermo O’Donnell chama de "democracia delegativa”, que combina eleições livres, competitivas e formalmente institucionalizadas com instituições políticas não formalizadas e práticas autoritárias. Um elemento notável desse arranjo é a crença de que o presidente, por ter sido eleito por uma maioria, tudo pode e dele tudo é cobrado. A reduzida accountability horizontal, a pouca transparência dos processos de tomada de decisão das políticas governamentais, a grande distância entre as normas formais e o funcionamento concreto da maioria das instituições políticas e as concepções e práticas delegativas terminam por reviver e acentuar características do antigo autoritarismo (Santos, 2001).

Ainda que a autoridade do governo venezuelano tenha respaldo em uma série de eleições e tenha passado pela prova de um referendo, é inegável a fragilidade institucional, o déficit de prestação de contas horizontal e a relação direta estabelecida entre Chávez e seu eleitorado, típica da democracia delegativa. O chavismo corre o risco de transformar-se, 
assim, em uma ameaça à democracia, que, apesar de todas as debilidades, tende a ser hoje o único jogo de poder (“the only game in town”) na América do Sul.

\section{3 - INSERÇÃO INTERNACIONAL}

As possibilidades de desenvolvimento dos países da América do Sul dependem do tamanho da economia, sua participação no cenário internacional e a diversificação de sua base produtiva. O estilo de inserção no sistema internacional e as respostas aos desafios e oportunidades da globalização têm impacto sobre o desenvolvimento, mas o que parece favorecer os países da região é o ambiente de redefinição das relações econômicas internacionais marcadas há décadas por desiguais lutas de poder entre países centrais e periféricos.

Neste contexto, segundo Cervo (2003), a política externa do governo de Lula possui quatro linhas de força. Uma delas tem por objetivo sanar dependências estruturais e promover a inserção interdependente. Para atenuar a vulnerabilidade externa, Lula projeta um modelo assertivo de inserção no mundo globalizado, introduzindo remédios de equilíbrio aos males da globalização assimétrica, que distribui benefícios ao centro e os impede de chegar aos países em desenvolvimento, teoria desenvolvida pelo ex-presidente Fernando Henrique Cardoso.

Essa ação desenvolve-se em quatro frentes: reforçar o núcleo central da economia nacional, estatal ou privado, de modo a recuperar a trilha do crescimento econômico; reconverter a política de comércio exterior em instrumento estratégico de desenvolvimento e gerador de superávits para aumentar a disponibilidade interna de divisas; reverter a curva de dependência financeira em que mergulhou o processo de desenvolvimento desde 1980, cerceando as vias de evasão de renda líquida nacional; e transitar da nacionalização da economia internacional à internacionalização da economia nacional, desde a plataforma regional (Cervo, 2003).

A recuperação do universalismo e do bilateralismo é outra linha de força. A visão de mundo da diplomacia do presidente Lula projeta como ideal a reorganização da ordem em um mundo multipolar.

A terceira linha de força da política externa do governo de Lula é o reconhecimento da América do Sul como espaço natural de afirmação dos interesses brasileiros, com o reforço das economias nacionais pela via da regionalização e da autonomia 
decisória na esfera política e a rejeição às intervenções externas na solução de problemas de segurança regional.

Por último, Lula manteve o acumulado histórico da diplomacia brasileira, ou seja, a defesa dos princípios da autodeterminação e não intervenção, a promoção do nacionalismo cooperativo e não confrontacionista, a valorização do pacifismo na política internacional, o zelo pelo respeito aos estatutos jurídicos da ordem e a preservação da cordialidade oficial com os vizinhos.

A política externa de Lula revelou-se próxima a de Hugo Chávez, sobretudo no que diz respeito ao conceito político e estratégico da América do Sul. A ênfase da política externa venezuelana foi posta na vizinhança. O governo de Chávez decidiu jogar seu peso político, e a força de seu mercado e de seu setor produtivo, particularmente o petróleo, em favor da integração regional (Cervo, 2001).

São dois os eixos fundamentais que guiam o modelo chavista de política externa: o uso dos recursos energéticos como base para a integração regional e o discurso alinhado a um projeto socialista. A Venezuela ostenta o “ideal bolivariano” de integração política e maior disposição na esfera da integração energética e econômica com projetos de grande porte, como o Gasoduto do Sul e o Banco do Sul.

Houve, no entanto, uma inflexão. Os interesses que dominam a política externa da Venezuela e a forma como esta enxerga seu papel na América do Sul já não coincidem ou se sobrepõem às idéias brasileiras. Segundo Villa (2007), o distanciamento venezuelano e brasileiro revela, primeiramente, que os países sul-americanos, mesmo os que parecem ter algumas coincidências ideológicas, não têm um projeto de política externa em comum. Dentro da esquerda de diferentes tonalidades na América do Sul, que vai de um espectro mais radical ao centro, parecem existir três projetos de política externa.

Um deles é representado pelos países fundadores do Mercosul que, apesar das sucessivas crises, compartem de que é necessário manter a autonomia do bloco com uma agenda positiva em relação aos Estados Unidos. Um segundo projeto é mais orientado a uma relação forte com os Estados Unidos, em que se insere o Chile, menos por razões ideológicas e mais por razões econômicas, sobretudo pela concordância da elite chilena com os Estados Unidos e seu modus operandis de inserção nos mercados globalizados. E, finalmente, há uma proposta mais radical, em que são inseridos basicamente três países andinos - Bolívia, Equador e Venezuela.

Promotor desta proposta, Chávez tem buscado ampliar as relações da Venezuela na América do Sul e fora dela, diversificando parceiros e apostando na 
multipolarização das relações internacionais, mas o faz incrementando os laços com a Rússia e o Irã, adversários dos Estados Unidos. O Brasil, ao contrário, adensou as relações com os Estados Unidos, por exemplo, por meio das negociações para a produção de etanol, adotando uma percepção mais realista.

Villa (2007) acrescenta que o distanciamento diplomático entre Brasil e Venezuela revela a existência de diferenças substantivas na concepção do processo de integração. A Venezuela concebe um processo de integração em bases não só econômicas, mas também profundamente políticas. Também entende a integração como um processo anticapitalista, coerente com sua visão do "socialismo do século XXI”, o que se distancia da visão moderada, com forte ênfase na natureza econômica, do processo de integração sustentado pelo Brasil.

Para o autor, as diferenças entre Brasil e Venezuela estão em um nível em que ainda podem ser tratadas diplomaticamente, mas não são de estilo, e sim substantivas. E têm como pano de fundo a disputa pela liderança da América do Sul. 


\section{2 - RECURSOS DE PODER}

A política externa de Brasil e Venezuela, inaugurada por Lula e Chávez, deu alta prioridade às relações com a América do Sul, o que, segundo Villa (2007), tem resultado em uma dinâmica dupla de cooperação e conflito. O principal recurso de poder venezuelano, o petróleo, tem permitido que Chávez adote um comportamento unilateral e abertamente intervencionista, de cooptação de aliados e de construção de uma liderança sobre o subcontinente. Sua política externa revestida de forte conteúdo ideológico contrasta com a diplomacia de "perfil alto” de Lula, que procurou apresentar uma postura assertiva, em defesa da soberania e dos interesses nacionais, de alianças com países em desenvolvimento, e dos processos de integração da América do Sul (Almeida, 2004).

O Brasil procurou um caminho próprio - e até certo ponto alternativo - de ação no cenário internacional, dando nova ênfase à defesa do multilateralismo para o tratamento de situações de crise de segurança e política internacional. Também tornou-se uma preocupação de sua política externa ampliar o diálogo político com outras potências intermediárias, como África do Sul e Índia, e com potências mundiais, como China e Rússia. As afinidades com os Estados Unidos serão eventualmente encontradas em relação à agenda regional, particularmente em situações nas quais as instituições democráticas estejam em condições de risco. A clara disposição do governo brasileiro de atuar mais ativamente em situações de turbulência política na América do Sul abriu, simultaneamente, um novo campo de diálogo e de diferenças com os Estados Unidos (Hirst, 2006).

No que se refere à disputa pela liderança da América do Sul, Lula e Chávez contam com o etanol e o petróleo, respectivamente, e aliados estratégicos como recursos de poder.

\section{2 - PETRÓLEO VERSUS ETANOL}

O papel do petróleo é peça chave para compreender o ativismo venezuelano, que, segundo Cervo (2001), apóia-se em duas percepções: a superioridade econômica advinda do petróleo e a superioridade política advinda da tradição democrática, inaugurada por Rômulo Betancourt, em 1959. A primeira teria como alicerce o fato de a Venezuela ter sido nos anos 50 o segundo produtor mundial e o primeiro exportador mundial de petróleo, o que lhe permitiu atrair capitais e investimentos norte-americanos. A segunda se expressa na Doutrina Betancourt, uma determinação de somente reconhecer governos oriundos de eleições 
realizadas segundo normas constitucionais. Ocupando uma posição geográfica estratégica entre o Caribe e a América do Sul, acrescenta o autor, a Venezuela tinha ambições de peso sobre o hemisfério.

Assim, três vertentes passaram a condicionar a ação externa da Venezuela em seu âmbito regional: a dependência das exportações de petróleo; a dependência dos Estados Unidos, principal investidor, cliente e fornecedor; e a repercussão interna dos acontecimentos políticos na área do Caribe.

Nos anos 70, porém, a Venezuela passou a empreender ações regionais destinadas a criar laços com os países vizinhos, cujo consumo de petróleo desejava prover. A alta dos preços permitiu ao país, agora sob o governo de Carlos Andrés Pérez Rodriguez, substituir a Doutrina Betancourt pelos sonhos bolivarianos de liderar a América Latina. Naqueles anos, as visões geopolíticas de Brasil e Venezuela já eram conflitantes. A Venezuela estava disposta a jogar com o peso do petróleo em favor da liderança pretendida sobre a região. A história repete-se com Hugo Chávez.

A riqueza petrolífera da Venezuela, quinto maior exportador mundial de petróleo cru, impulsiona o comportamento unilateral de Chávez e sua intervenção em assuntos internos de países sul-americanos, sobretudo em seus processos eleitorais. Nas eleições peruanas de 2006, por exemplo, Chávez foi acusado pelo então presidente Alejandro Toledo de intervir em favor do candidato Ollanta Humala. O venezuelano trocou acusações com o adversário de Humala, Alan García, e ameaçou interromper as relações diplomáticas caso este saísse vitorioso. O presidente Alejandro Toledo afirmou que não aceitaria ameaças, chantagens nem intromissões da Venezuela nos assuntos domésticos peruanos, e retirou seu embaixador em Caracas. Chávez fez o mesmo. Toledo recorreu à Organização dos Estados Americanos (OEA) para impedir interferências de Chávez no processo eleitoral do Peru, provocando a reação do ministro das Relações Exteriores da Venezuela. Este avaliou a crise entre Caracas e Lima como fruto de uma campanha planejada por Washington, acrescentando que o candidato Alan García, consciente de sua “debilidade”, estaria explorando o fator Chávez a seu favor (OPSA, n.4, 2006).

Após intenso tiroteio verbal - Chávez chegou a insultar García, chamando-o de "bandido" e "irresponsável”, e acusou Toledo e o candidato de serem "subordinados ao Império" - o governo peruano designou seu embaixador em Caracas, pondo fim ao conflito em janeiro de 2007 (OPSA, n.1, 2007).

O fato é que, por meio da diplomacia do petróleo, Chávez tenta ampliar suas esferas de influência, para construir sua liderança sobre a América do Sul. A riqueza 
petrolífera permitiu, por exemplo, que o venezuelano comprasse, entre 2005 e 2007, US\$ 5,636 bilhões de bônus da dívida argentina (OPSA, n. 6, 2007). E, neste período, a Argentina nunca esteve tão próxima da Venezuela.

Segundo Pérez Llana (2007), a Argentina do ex-presidente Nestor Kirchner, em vez de contribuir para a construção de um mundo multipolar, com ênfase na cooperação e no multilateralismo, considerou mais apropriado aderir às coalizões estabelecidas, privilegiando um "soft balancing”, em outras palavras, recursos de poder concebidos a serviço de uma política de hostilidade ao hegemônico. Venezuela, Cuba, Bolívia, Equador, Irã e Rússia seriam os arquétipos. O autor acrescenta que a política externa do governo de Kirchner, de aproximação com Caracas, pouco coincide com a política dos vizinhos do Cone Sul, que priorizam outro tipo de padrão internacional, buscando mercados, investimentos e subscrevendo acordos comerciais.

Pérez Llana (2007) afirma que, no que se refere às alianças comerciais, ainda que tudo faça crer que a prioridade diplomática da Argentina deveria concentrar-se multilateralmente no Mercosul e bilateralmente no Brasil e no Chile, a realidade é outra. O aliado é a Venezuela de Chávez. Uma aliança entre Buenos Aires e Caracas teria um duplo fim: fortalecer a Argentina e conter as supostas aspirações de influência regional do Brasil (Tokatlian, 2004).

Energia é poder. A geopolítica energética nas Américas Central e do Sul e no Caribe é uma disputa entre Brasil e Venezuela, ainda que nenhum dos dois países admita. E as relações brasileiras e venezuelanas com os demais países da região se orientam cada vez mais por meio da matriz energética. Desse modo, a participação da Venezuela no processo de nacionalização do gás boliviano foi um divisor de águas na relação com o Brasil. Às divergências entre os dois países, deve ser somada a iniciativa brasileira de lançar o etanol como alternativa ao petróleo, o que ganhou relevância em tempos de mudanças climáticas.

O álcool deu ao Brasil uma liderança relevante na discussão das alternativas energéticas. Apesar da conquista da auto-suficiência em petróleo, anunciada com pompa em abril de 2006, e a descoberta do campo de Tupi, que aumentaria em até $60 \%$ as reservas de petróleo e gás da Petrobrás, o governo brasileiro mantém o esforço para exportar a tecnologia dos biocombustíveis. A produção de energia renovável, argumenta, tem como resultado o respeito ao meio ambiente, um forte impacto social e a capacidade de gerar empregos. Os biocombustíveis seriam capazes de reduzir a emissão dos gases do efeito estufa, que contribuem para o aquecimento global, e de enfrentar a estagnação do emprego e a concentração de renda. 
Segundo a diplomacia brasileira, a produção de biocombustíveis ganha relevância estratégica à medida que aumentam os preços do petróleo, conseqüência da elevada demanda por parte da China, Índia e Estados Unidos e da preocupação com a garantia de fornecimento devido à instabilidade política nas principais regiões produtoras de combustíveis fósseis no mundo. O governo brasileiro ressalta que o nível de preços do petróleo pode impor limites indesejáveis ao crescimento da economia mundial. Do ponto de vista ambiental, os ganhos com o uso de biocombustíveis são significativos. Segundo o Itamaraty, a utilização de etanol significou, entre 1970 e 2005, a não emissão de 644 milhões de toneladas de CO2.

O Brasil, contudo, precisou responder acusações de que a produção de etanol comprometeria a soberania alimentar. Chávez, Morales e Castro levantaram a bandeira antietanol, com o argumento de que a extensão de cultivos para produção de biocombustíveis poderia levar à fome no mundo, pelo uso das áreas hoje destinadas à plantação de alimentos. A postura da esquerda radical coincidiu com a disposição do governo dos Estados Unidos de diversificar sua matriz energética e avançar na parceria com o Brasil para o desenvolvimento dos biocombustíveis.

Resumidamente, enquanto Chávez endurece o discurso contra os Estados Unidos, Lula estreita os laços com George W. Bush, a quem o venezuelano chamou de “cadáver político”. A idéia de Lula é unir a tecnologia brasileira com o capital estrangeiro para produzir etanol nos países pobres.

Dessa forma, a matriz energética é parte da disputa travada hoje na América do Sul. De um lado, uma matriz limpa e o desenvolvimento do biodiesel como alternativa aos combustíveis fósseis, que são a base, do outro lado, de uma matriz esgotável, altamente poluente e ineficiente.

Porém, se, para Lula, a aliança do Brasil com os Estados Unidos interessa pela produção de etanol, para Bush, vai mais além. O presidente brasileiro, líder da esquerda moderada, teria potencial para neutralizar os impulsos de Hugo Chávez, o que ainda não se confirmou.

\section{3 - ALIANÇAS}

Lula e Chávez apostaram na diversificação de parceiros e na multipolarização das relações internacionais, mas a Venezuela adotou uma diplomacia baseada em identidades ideológicas, ao passo que o Brasil desenvolveu uma postura pragmática, buscando aliados 
para cada problema, contestando sem desafiar os grandes, respeitando, sem respaldar a posição de países problemáticos, como Venezuela, Cuba, Líbia e Síria, por exemplo.

Chávez, ao contrário, reforça os laços com esses países, provocando inquietudes, colocando à prova a estabilidade da América do Sul. Com a Rússia, Irã e China, o venezuelano firmou convênios em matérias de hidrocarbonetos, petroquímica, mineração e siderurgia. Entre eles, destacam-se os assinados pela PDVSA com 23 empresas russas para transferência de tecnologia sobre exploração e produção de hidrocarbonetos (OPSA, n. 5, 2006). Com a China, foi firmado acordo para a criação de três empresas mistas de refino e transporte de petróleo. A estatal venezuelana PDVSA construirá duas refinarias, uma na Venezuela e outra em território chinês, e constituirá uma empresa de transporte petrolífero. Segundo o presidente da Venezuela, os empreendimentos possibilitarão que, até 2012, o país forneça um milhão de barris diariamente à China, sendo que atualmente são 200 mil (OPSA, n. 2, 2007).

A aliança com o Irã talvez seja a mais bem-sucedida do esforço de Chávez para juntar-se aos países diplomaticamente distantes dos Estados Unidos, como a Rússia, principal fornecedor de matéria bélico para a Venezuela, e a China, interessada nas reservas de petróleo venezuelanas. Nenhuma dessas aproximações, entretanto, repete a química entre Chávez e Ahmadinejad. Com o presidente do Irã, foi lançada a proposta de criação de uma entidade que defenda dos interesses dos países produtores e exportadores de gás - conhecida como OPEP do gás (Folha de São Paulo, 2007).

Com aliados como esses, o líder da esquerda radical sul-americana mantém tensas e turbulentas relações com os Estados Unidos. O documento Estratégia de Segurança Nacional para os Estados Unidos, assinado pelo presidente George W. Bush em março de 2006, coloca a Venezuela entre os casos que demandam atenção mundial por seu potencial desestabilizado (OPSA, n.2, 2006).

Um dos elementos que alimentam o clima de confronto entre os dois países é a compra de armamentos pelo governo venezuelano. O governo de George W. Bush não liberou a licença para a venda de aviões militares à Venezuela pela Empresa Brasileira de Aeronáutica (Embraer), dotados de tecnologia norte-americana, sendo que a mesma postura não foi verificada com relação ao Chile, que adquiriu 18 caças da Holanda. A decisão norteamericana foi contestada pela diplomacia brasileira. O ministro das Relações Exteriores, Celso Amorim, considerou “contraproducente” a tentativa norte-americana de obstruir a venda de aviões para a Venezuela (OPSA, n.1, 2006). 
No mesmo ano, a Venezuela recebeu um lote de 30 mil fuzis russos AK-103 e munições como parte do programa de modernização das Forças Armadas. A operação, acordada em 2004, incluiu a compra de helicópteros militares. A Rússia reiterou que continuaria fornecendo armas e equipamentos militares à Venezuela apesar do embargo norteamericano. Os dois países também negociaram a aquisição de aviões de combate e a instalação de uma fábrica de armamentos com tecnologia russa em território venezuelano. $\mathrm{O}$ Departamento de Estado dos Estados Unidos mostrou-se preocupado com o incremento da capacidade militar da Venezuela e declarou que tentaria impedir que a Rússia concretizasse a venda dos aviões de combate (OPSA, n. 5, 2006).

Lula também deu ênfase à multipolaridade, inaugurando, porém, uma diplomacia “altiva e ativa”, para usar as palavras de seu chanceler Celso Amorim. Ocupou-se o Itamaraty em trilhar o caminho da busca da autonomia, da transformação do Brasil em um global player e do equilíbrio nas relações internacionais.

Já no discurso de posse, em $1^{\circ}$ de janeiro de 2003, Lula antecipou que o Brasil combateria o protecionismo e trataria de obter regras mais justas e adequadas à condição de país em desenvolvimento. Acrescentou o presidente que seu governo buscaria a eliminação dos escandalosos subsídios agrícolas dos países desenvolvidos que prejudicam os produtores brasileiros, privando-os de vantagens comparativas. Lula afirmou ainda que o ser humano é o destinatário último do resultado das negociações comerciais e que seu governo estaria atento para que essas negociações, muito além de meras reduções tarifárias, não criassem restrições inaceitáveis ao direito soberano do povo brasileiro de decidir sobre seu modelo de desenvolvimento.

Na área comercial, portanto, tratou a diplomacia brasileira de expandir o comércio com a China, a Índia e a América do Sul, entendendo que a base econômica, e não exclusivamente política, deveria lastrear sua liderança sobre o subcontinente e que ela exigia o aumento das trocas comerciais, no contexto de um comércio regional mais equilibrado (Moniz Bandeira, 2006). Neste sentido, o volume das exportações brasileiras para o Mercosul, por exemplo, cresceu 31\% entre 2004 e 2005, e 20,4\% entre 2005 e 2006, saltando de US\$ 8,9 bilhões em 2004 para US\$ 13,9 bilhões em 2006 (Santana e Kasahara, 2007).

Ademais, o Brasil ampliou seu espaço de atuação internacional em "iniciativas de geometria variável”, de modo a negociar e barganhar com mais força a agenda internacional do país (Vizentini, 2006). Um exemplo é o G-20, constituído em 2003, sob a liderança do Brasil, nas reuniões preparatórias para a V Conferência Ministerial da Organização Mundial do Comércio (OMC), realizada em Cancun, no México. 
A idéia do G-20, formado por países que representam quase $60 \%$ da população mundial e $70 \%$ da população rural em todo o mundo, é pressionar os países ricos pela liberalização agrícola. O comunicado final da Primeira Reunião Ministerial do G-20, em Brasília, em dezembro de 2003, expressou assim os objetivos do grupo:

O G-20 é uma coalizão de países formada para tratar das preocupações de seus membros, que são também comuns à maioria dos países em desenvolvimento, no que se refere a eliminação de práticas que distorcem o comércio e a produção agrícolas; a busca de aumento substancial de acesso a mercados; e seu desenvolvimento rural, segurança alimentar e/ou necessidades de subsistência dos agricultores nesses países.

Os ministros reiteraram que uma efetiva liberalização e reforma do comércio agrícola, que abarquem as barreiras e distorções ao comércio, dariam uma grande contribuição aos objetivos de desenvolvimento da Rodada de Doha da OMC. Além disso, defenderam que a liberalização auxiliaria no tratamento da deterioração dos preços dos produtos de base e que a eliminação das barreiras e distorções no comércio agrícola poderia também contribuir para a transformação econômica, redução da pobreza e promoção da estabilidade política e social nos países em desenvolvimento.

Considere-se ainda que, no âmbito da OMC, o Brasil foi obtendo diversas vitórias em disputas consideradas desleais pelo governo brasileiro, dentro da tradição normativa e legalista do Itamaraty.

Paralelamente à formação do G-20, o governo brasileiro articulou o G-3, reunindo Brasil, Índia e África do Sul, o que, segundo Vizentini (2006), produziu fato político de bastante impacto. Além da cooperação técnica e possibilidades de integração entre países em desenvolvimento, estão as questões políticas, que envolvem o reordenamento do sistema internacional e a reforma do Conselho de Segurança das Nações Unidas, incluindo o pleito brasileiro de um assento permanente.

Vizentini (2006) chama a atenção para o fato de que aliança estratégica do G-3 seja observada não apenas como um reforço “contra os países ricos”, mas também como um reforço mútuo, extra-continental, às pretensões da Índia, Brasil e África do Sul de manterem ou reforçarem suas respectivas lideranças nos seus sub-continentes.

Na realidade, ao sul move-se o Brasil com mais efeito, usando parcerias bilaterais, coalizões de países ou processos de integração na América do Sul, tendo em vista, 
precisamente, dobrar os países ricos pela negociação multilateral e leva-los à eliminação de subsídios agrícolas e entraves à entrada de produtos dos países em desenvolvimento (Cervo, 2006).

Lula busca exercer uma liderança regional e internacional para mudar substantivamente e trazer justiça ao mundo, bem como implantar uma "nova geografia comercial”. Os contornos não foram muito bem definidos, mas ela tem a ver com uma presença mais afirmada dos países em desenvolvimento nas negociações comerciais e nas decisões sobre acesso desimpedido aos mercados (Almeida, 2004).

É inegável que o Brasil tem e continuará tendo um papel fundamental na América do Sul. Contudo, a diplomacia venezuelana, amparada na força dos petrodólares, impõe desafios relevantes às pretensões brasileiras na região, à medida que potencializa tensões e conflitos, e promove a polarização entre os países. O novo eixo formado por Caracas-La Paz-Havana configura um constrangedor desafio à liderança brasileira escorada na promessa do etanol, no projeto de integração regional ainda baseado na precária estrutura do Mercosul, e nas alianças com países do Sul. 


\section{3 - CONFLITOS}

Em seu discurso de posse, Lula advertiu que a grande prioridade da política externa de seu governo seria a construção de uma América do Sul politicamente estável, próspera e unida, com base em ideais democráticos e de justiça social. Para isso, explicou, seria essencial uma ação decidida de revitalização do Mercosul, enfraquecido pelas crises de cada um de seus membros e por visões muitas vezes estreitas e egoístas do significado da integração. O presidente brasileiro afirmou que o Mercosul, assim como a integração da América do Sul em seu conjunto, é, sobretudo, um projeto político. Mas esse projeto repousa em alicerces econômico-comerciais que precisam ser urgentemente reparados e reforçados.

Em seguida, Lula mostra disposição em contribuir para a estabilidade na América do Sul, ao lembrar que vários dos nossos vizinhos vivem situações difíceis. “Contribuiremos, assegurou o presidente, desde que chamados e na medida de nossas possibilidades, para encontrar soluções pacíficas para tais crises, com base no diálogo, nos preceitos democráticos e nas normas constitucionais de cada país”.

Souto Maior (2003) avalia que a proclamada disposição do presidente Lula de, sem veleidades de intervencionismo, participar ativamente da política sul-americana não se limita ao esforço integracionista, ou seja, o Brasil se propõe um papel protagônico entre os países em desenvolvimento da América do Sul, área na qual se considera em condições de exercer uma liderança natural.

Na visão do autor, a diplomacia de Lula adotou um discurso político de potência regional, que se afasta de algumas atitudes tradicionais da nossa diplomacia. Em vez de negar a intenção de exercer qualquer forma de liderança na América do Sul, o atual governo parece considerá-la algo natural. Nomeado, o ministro das Relações Exteriores, Celso Amorim, declarou que "liderança não é objetivo em si, mas decorrência de certas posições. Ela se exerce mais por inspiração do que por comando”. Empossado, reafirmou que o Brasil não fugiria de um protagonismo engajado, sempre que fosse necessário para a defesa do interesse nacional.

A “assunção ostensiva” do papel de líder, que a diplomacia brasileira procurara manter ausente, deu-se quando o chanceler afirmou "que há um anseio por liderança no mundo. E o presidente Lula corresponde um pouco a uma imagem de algo que está faltando”. Portanto, ficou claro no primeiro mandato de Lula que o Brasil se considera um líder natural na América do Sul, embora tal liderança não tenha qualquer sentido autoritário (Souto Maior, 2003). 
Convém ressaltar que protagonismo e liderança são termos quase sempre interpretados de maneira negativa, e a associação à idéia de imperialismo é quase automática (Gonçalves e Lyrio, 2003). Entretanto, para Moniz Bandeira (2003), o novo discurso pode ser interpretado como uma manifestação de auto-confiança e de coerência com a defesa de uma ordem internacional democrática. O Brasil, na visão do autor, não estaria preocupado com a possibilidade de que, ao proclamar-se líder regional, pudesse ferir suscetibilidades e, conseqüentemente, pôr em risco a própria liderança. Esta seria tão evidente que ninguém teria por que se melindrar ao vê-la publicamente declarada. Na verdade, repetindo Jaguaribe, "nenhum brasileiro pensa em si mesmo como hegemônico; de fato, ele nem sequer pensa no assunto” (Turner, 1991).

Hugo Chávez, por sua vez, aspira o papel de ator regional sem que haja correspondência, com exceção do petróleo, na dimensão de seus recursos de poder, tais como tamanho geográfico, populacional e econômico, e aliados estratégicos. Tais pretensões tampouco correspondem com o tamanho de seus problemas internos.

A Venezuela de Chávez tem demonstrado crescente interesse em mobilizar os recursos de política externa, basicamente o petróleo, para desenvolver um papel protagonista na América do Sul, confrontando-se com a agenda de política externa brasileira para a região. Esse objetivo mistura elementos ideológicos com recursos políticos pragmáticos. Exatamente essa imagem do homem movimentado por idéias e preconceitos tem alimentado as desconfianças de setores domésticos em países sul-americanos governados pela esquerda moderada, como Brasil e Chile (Villa, 2007). Às desconfianças, sucedem-se os contenciosos, analisados a seguir.

\section{1 - MERCOSUL VERSUS ALBA}

Injetando novo vigor no Mercosul, o governo de Lula visava o fortalecimento do bloco para transformá-lo em espaço de afirmação da liderança brasileira. O Brasil dispôsse, com Lula, a assumir os custos e responsabilidades da ênfase acrescida ao papel do Mercosul, ou seja, propôs-se a liderar o bloco - e, a mais longo prazo, a América do Sul - de acordo com as normas acordadas entre os países da região e com vistas a uma distribuição eqüitativa de ganhos. É como se dispusesse a ser uma espécie de líder constitucional e democrático da região (Souto Maior, 2003).

O que claramente não está assegurado é que nossos vizinhos vejam as coisas da mesma maneira ou sequer confiem nas intenções declaradas pelo governo brasileiro. Um 
exemplo é a oscilante relação mantida por Lula e Kirchner, explicada, parcialmente, pela percepção argentina de que o brasileiro reivindicou, de forma um tanto ostensiva, a liderança do Mercosul (Neto, 2007). O governo de Lula tem mantido o Mercosul como uma das prioridades da agenda de política externa, mas dificuldades do próprio processo de integração e acusações de que o Brasil tem buscado a liderança regional a qualquer custo, sem levar em consideração os interesses dos países vizinhos, aumentam as percepções negativas sobre o bloco (Onuki, 2006).

Na realidade, as assimetrias estruturais das economias dos países membros do Mercosul, sobretudo do Paraguai e Uruguai, aliadas à emergência do nacionalismo econômico, provocaram o inverso do que se espera de um processo de integração, ou seja, protecionismo. A vitória de candidaturas de esquerda na América do Sul trouxe a volta do nacionalismo como ideologia orientadora das ações de governo. E os problemas gerados pelas diferenças estruturais entre o perfil econômico e a inserção internacional dos países do bloco tornaram-se explosivos com a adoção de estratégias nacionalistas de recuperação econômica. Enfraqueceram-se, desse modo, os incentivos para dar prioridade ao projeto integracionista sul-americano (Lima e Coutinho, 2006). Tornaram, assim, evidentes as desconfianças sobre o quanto os países estavam dispostos a investir em um projeto de integração que viveu mais de crises do que de eficácia. E até que ponto estariam dispostos a cooperar, em um espaço ampliado, dividindo os escassos benefícios.

As desconfianças, é preciso salientar, motivaram a defesa de um Mercosul livre de qualquer tentativa hegemônica pelos presidentes do Uruguai, Tabaré Vázquez, e da Venezuela, Hugo Chávez, em declaração conjunta após encontro oficial em março de 2006 em Caracas (OPSA, n. 2, 2006).

No contexto da mais recente crise enfrentada pelo Mercosul, Chávez passou a condicionar a participação da Venezuela no bloco à sua reformulação profunda, pois já não interessaria àquele país o ingresso no “velho Mercosul”, para usar suas palavras.

Uma questão delicada é o modo como o Mercosul se relaciona com os Estados Unidos. A esquerda moderada tem o papel crucial de evitar um confronto maior com os Estados Unidos, ao mesmo tempo em que reduz a instabilidade regional enquanto crises políticas e domésticas e conflitos de fronteira continuam ativos (Lima e Coutinho, 2006).

Neste sentido, ao lado dos governos da esquerda radical, como Cuba, Nicarágua, Equador e Bolívia, a Venezuela promoveu o bloco conhecido como Alba (Alternativa Bolivariana para a América Latina e o Caribe), uma espécie de integração soberana, capaz de combater a influência dos Estados Unidos sobre os países da região. O 
projeto da Alba, tal como Chávez o deseja, prevê a cooperação militar e de inteligência, e um pacto de defesa, uma resposta, segundo o venezuelano, contra o "terrorismo e agressão permanentes dos Estados Unidos”.

Sem dúvida, a liderança venezuelana encontraria mais espaço em um bloco como a Alba. O problema, como sugere Villa (2007), é que o conteúdo alternativo da proposta da Alba não demoraria em se chocar com o conteúdo mais pragmático do Mercosul. E na primeira reunião dos países membros, Chávez enviou claros sinais do distanciamento ao afirmar: "Somos obrigados a avançar cada dia mais rapidamente e de forma mais precisa”.

Foi deflagrada, neste momento, uma crise entre Brasil e Venezuela só antes vista durante a nacionalização do gás boliviano. Em resposta às declarações de parlamentares brasileiros contrários a não renovação da concessão da emissora venezuelana RCTV, Chávez declarou que o Congresso do Brasil era um “papagaio de Washington” e estava dominado por grupos de direita dispostos a impedir a entrada de seu país no Mercosul. O presidente Lula não comentou o fechamento da RCTV, mas, em nota oficial, repudiou manifestações que pusessem em questão a independência, a dignidade e os princípios democráticos das instituições brasileiras.

Novo embaraço para a diplomacia brasileira foi gerado pela ameaça de Chávez de desistir do ingresso no Mercosul, caso o processo de adesão, cujo protocolo já havia sido assinado pelos países-sócios do bloco, não fosse concluído em três meses. Faltava a ratificação pelos Parlamentos de Brasil e Paraguai. Confirmando o que teria sido uma retórica ambígua, a la Chávez, as visitas do embaixador venezuelano no Brasil ao Congresso brasileiro e as declarações do próprio Chávez liberando o Executivo brasileiro de responsabilidade pela demora na aprovação do protocolo de ingresso da Venezuela no Mercosul atenuaram a crise.

O embaixador venezuelano, deixando de lado convicções ideológicas, assegurou que "não houve intenção alguma do presidente Chávez em dar um ultimato ao Congresso”, acrescentando que, “o que há é um mercado venezuelano interessado no ingresso no Mercosul” (OPSA, n. 4, 2007).

Lima e Kfuri (2007) avaliam que a adesão da Venezuela à integração regional aumentaria o peso da região na política mundial por agregar recursos econômicos, em especial energéticos, que estão se tornando escassos no mercado mundial. Na avaliação do governo brasileiro, um Mercosul forte aumentaria seu poder de barganha nas negociações com os países ricos e a adesão da Venezuela, neste sentido, era de extrema importância para as pretensões brasileiras. Além disso, o ingresso da Venezuela agregaria valor ao pólo 
regional, em um contexto de concentração do poder mundial, permitindo quer a consideração dos interesses regionais na elaboração das normas e regras multilaterais, quer o exercício de um equilíbrio suave para impedir que ações e normas indesejáveis sejam aplicadas à região.

Chávez tem, portanto, demonstrado uma boa capacidade de iniciativa diplomática e econômica, que se choca com a liderança brasileira na América do Sul. Para Villa (2007), o Brasil percebeu que Hugo Chávez leva a sério o projeto de construção de uma liderança regional. De aliado, o vizinho passou a concorrente em potencial. No plano mais concreto, essa capacidade chavista de iniciativa tem incluído propostas de envergadura para avançar na integração sul-americana.

\section{2 - INTEGRAÇÃO ENERGÉTICA}

A busca pela integração energética ganha impulso no momento em que os países sul-americanos (e não somente eles) enfrentam uma crise, agravada pela instabilidade política nos países andinos, em um setor crucial para o desenvolvimento econômico (Alexandre e Pinheiro, 2005). Mas há um descompasso entre moderados e radicais quanto à estratégia energética a ser seguida pela América do Sul. A coexistência do nacionalismo econômico em alguns países com políticas econômicas de corte liberal em outros tem conduzido a divergências, que dificultam a formulação de propostas de integração em várias áreas. Visões muito distintas sobre o papel do Estado na economia e sobre prioridades de inserção internacional dificultam, quando não inviabilizam, a integração em algumas áreas onde se encontram grandes oportunidades econômicas, como a cooperação energética.

A nacionalização dos recursos energéticos da Bolívia, decretada por Evo Morales naquele $1^{\circ}$ de maio de 2006, foi um divisor de águas para a esquerda sul-americana, sobretudo pela maneira diplomaticamente desastrada como fora feito, confrontando os interesses brasileiros. A ocupação das instalações da Petrobrás na Bolívia foi classificada pelo governo brasileiro como um gesto espetaculoso e desnecessário. O presidente da Petrobrás considerou a postura de Morales como um "gesto inamistoso" e anunciou a suspensão dos investimentos da empresa na Bolívia.

O presidente Lula, por outro lado, adotou um tom ameno, reconhecendo a soberania boliviana, o direito de controlar seus recursos naturais, não escapando, contudo, das críticas pela postura moderada, na linha da esquerda que lidera. Segundo as estimativas do governo da Bolívia, a nacionalização aumentaria em 69\% a arrecadação dos impostos que 
incidem sobre a produção de hidrocarbonetos, elevando de US\$ 460 milhões para US\$ 780 milhões os recursos obtidos com a exploração dos recursos energéticos no país.

Contrariando o presidente da Petrobrás, Lula garantiu a manutenção dos investimentos da empresa na Bolívia e negou que houvesse uma crise entre os dois países. As declarações foram dadas após uma reunião de emergência na cidade argentina de Puerto Iguazú, da qual participaram também os presidentes da Argentina, Nestor Kirchner, e da Venezuela, Hugo Chávez. No encontro, que ficou conhecido como "Cúpula do Gás”, foi acertada a incorporação da Bolívia ao projeto do Gasoduto do Sul, que antes enfrentava restrições do governo brasileiro. Na verdade, o Brasil nunca revelou-se um entusiasta do projeto.

Apesar do discurso conciliatório de Lula, o conflito entre Brasil e Bolívia ameaçou a viabilidade do Gasoduto do Sul, um empreendimento de iniciativa venezuelana de aproximadamente oito mil quilômetros de extensão, que ligaria a cidade de Puerto Ordaz, na Venezuela, às margens do Rio da Prata, na Argentina, passando pelo Brasil, estimado em US\$ 23 bilhões. O ministro boliviano dos Hidrocarbonetos, Andrés Soliz Rada, declarou que a Petrobrás não poderia participar do projeto uma vez que $60 \%$ de suas ações pertencem a multinacionais. Em resposta, o ministro das Relações Exteriores, Celso Amorim, afirmou que, sem a Petrobrás, não haveria Gasoduto do Sul. A diplomacia presidencial, mais uma vez, precisou intervir para arrefecer as tensões, atribuindo à imprensa o novo mal estar.

O conflito ultrapassou as fronteiras bolivianas quando o governo brasileiro transmitiu seu desconforto a Chávez pela presença de técnicos da PDVSA nas instalações da Petrobrás no momento em que o presidente da Bolívia anunciava o decreto de nacionalização. O chanceler Celso Amorim afirmou que o presidente Lula teria afirmado que a postura de Chávez poderia colocar em risco não apenas o Gasoduto do Sul, mas a própria integração sulamericana. Em resposta, o ministério das Relações Exteriores da Venezuela divulgou um comunicado oficial considerando um equívoco considerar Evo Morales um homem sem personalidade, reduzido à influência de Chávez (OPSA, n. 4, 2006).

Para Villa (2007), possivelmente, o que mais preocupa o governo brasileiro é que a capacidade de influência de Hugo Chávez sobre a esquerda radical não seja feita de maneira responsável, o que pode fazer que o governo venezuelano perca a noção das conseqüências políticas de posturas abertamente intervencionistas. Na visão do autor, optando pela lógica dos ganhos relativos, o governo da Venezuela queria promover uma maior presença dos negócios petrolíferos na América do Sul, sacrificando os empreendimentos e discursos cooperativos. 
A nacionalização dos recursos energéticos da Bolívia transformou-se em oportunidade de expansão dos negócios da estatal PDVSA, única capaz de concorrer com a Petrobrás no subcontinente. Era claro, acrescenta Villa (2007), que, em algum momento, os interesses de empresas com um perfil semelhante veriam seus interesses se confrontarem. Vale ressaltar ainda que a Venezuela aproveitou-se do renascimento, entre setores da sociedade boliviana, da antiga imagem e do sentimento do Brasil como país imperialista, identificando a Petrobrás como expressão última desse comportamento brasileiro.

Villa (2007) avalia que, por mais que a política externa da Bolívia, como na Venezuela, seja atrelada ao valor estratégico de seus recursos energéticos, a decisão de Evo Morales de abrir confronto com o Brasil comprovou que Chávez tinha real influência sobre uma parte da esquerda da América do Sul, visão não compartilhada por Mireles (2006). Para este autor, a influência de Chávez sobre os governos da região andina tem sido superdimensionada. Segundo ele, é importante distinguir que, por trás do grandiloqüente discurso chavista e suas atitudes radicais, existe, na verdade, um estilo provocador de fazer política e não uma ameaça real à estabilidade regional.

Mireles (2006) acrescenta que o eventual apoio venezuelano a políticos nacionalistas emergentes e a presença mais ostensiva na Bolívia não indicam objetivamente que a influência de Chávez tenha se convertido relevante ao ponto de orientar a política interna ou externa de algum país da América do Sul.

De todo modo, após a crise provocada pelo decreto de nacionalização boliviano, Chávez e Morales assinaram um acordo para criação da Petroandina, empresa de capital misto formada pela boliviana YPFB, que teria 51\% das ações, e pela venezuelana PDVSA, que investiria US\$ 1,5 bilhões (OPSA, n. 4, 2006).

A América do Sul não tardou em assistir a um novo confronto entre moderados e radicais no que diz respeito à estratégia energética. Os ânimos acirraram-se, desta vez, pela possibilidade de diversificação da matriz energética da região e pela aproximação entre os presidentes dos Estados Unidos, George W. Bush, e do Brasil, Luiz Inácio Lula da Silva.

Em março de 2007, os dois assinaram o Memorando de Entendimento para Avançar a Cooperação em Biocombustíveis, que prevê estratégias para estimular a expansão da produção e do mercado de energia renovável em âmbito bilateral, com o estímulo à pesquisa e ao desenvolvimento de tecnologias relacionadas aos biocombustíveis de nova geração; com terceiros países, sobretudo na América Central e no Caribe, que serão encorajados à produção local e consumo de biocombustíveis; e em âmbito global, com a cooperação para o desenho de padrões uniformes e normas. A discussão em torno das taxas 
cobradas sobre o etanol vendido pelo Brasil para os Estados Unidos, no entanto, não entraram agenda (OPSA, n. 2, 2007).

Do Brasil, Bush partiu para Uruguai, Colômbia, Guatemala e México. Em protesto contra o giro do presidente norte-americano na América Latina, Chávez visitou Argentina, Bolívia, Nicarágua, Jamaica e Haiti, para assinatura de convênios na área energética. Em Buenos Aires, liderou um comício contra a presença de Bush na região, uma tentativa de ofuscar a viagem do presidente norte-americano. Com o governo da Nicarágua, Chávez acertou à construção de uma refinaria, no valor estimado de US\$ 2,5 milhões.

Dias depois, quando Lula e Bush se reuniram novamente, desta vez em Camp David, nos Estados Unidos, foram anunciados os primeiros países que receberão investimentos para o desenvolvimento de biocombustíveis - Haiti, República Dominicana, São Cristóvão e Névis e El Salvador.

A esquerda radical, no entanto, sofreu uma derrota na I Cúpula Energética SulAmericana, que reuniu representantes dos 12 chefes de Estado e de governo do subcontinente no mês seguinte à assinatura do acordo Brasil e Estados Unidos sobre biocombustíveis. A declaração final do encontro incluiu o reconhecimento do potencial dos biocombustíveis para a diversificação da matriz energética da região. Chávez admitiu que, apesar de sua postura contrária, a Venezuela precisava importar 200 mil barris diários de etanol. Neste sentido, o venezuelano acordou com Lula a retomada da importação do combustível sem tarifas alfandegárias.

Antes, porém, Cuba e Venezuela assinaram contratos para o fornecimento de cana-de-açúcar cubana para 11 plantas de etanol que seriam instaladas em território venezuelano. Os contratos, no âmbito do Plano Piloto Etanol, da PDVSA, prevêem o cultivo de 280 mil hectares de cana em 12 estados venezuelanos. Na ocasião, autoridades dos dois países declararam que a cooperação em torno do desenvolvimento de novas fontes de energia contribui para o bem-estar coletivo (OPSA, n. 2, 2007).

Em julho, Brasil e União Européia lançaram uma parceira estratégica, cujo comunicado conjunto defendeu a cooperação na área de biocombustíveis. De Lisboa, Lula seguiu para Bruxelas, onde participou da abertura oficial do Fórum Internacional de Biocombustíveis, que, integrado por África do Sul, Brasil, China, Estados Unidos, Índia e União Européia, é encarregado de promover o mercado internacional de etanol e biodiesel (OPSA, n. 4, 2007).

A cruzada do presidente Lula pela diversificação da matriz energética na América do Sul produziu novo desentendimento entre Brasil e Venezuela em agosto, durante 
a viagem de Lula aos países da América Central. O tema biocombustíveis sobressaiu-se nas visitas a Honduras, Jamaica e Panamá, com a inauguração de uma usina de etanol no segundo país.

A viagem de Lula ocorreu simultaneamente ao giro do presidente da Venezuela, Hugo Chávez, por países sul-americanos. Em visita à Argentina, Chávez e Kirchner assinaram um acordo que prevê a participação da PDVSA na exploração das reservas do Golfo de São Jorge, na Patagônia. No Uruguai, anunciou a compra de ações da empresa Alcoholes del Uruguai pela PDVSA. Na cidade boliviana de Tarija, o presidente venezuelano, novamente em encontro com Kirchner, anunciou, ao lado de Evo Morales, investimentos de US\$ 1,1 bilhão para impulsionar a Organização de Países Produtores e Exportadores de Gás da América do Sul. Por fim, no Equador, Chávez acordou com o presidente Rafael Correa a reativação das instalações do campo petrolífero de Sacha, o segundo do país em reservas (OPSA, n. 4, 2007).

É importante ressaltar que a multiplicação de acordos para investimentos firmados por Chávez com os países da América do Sul embaça a aposta que Lula faz na produção de etanol. Embora o raciocínio de Lula tenha fundamento e seja altamente sedutor países pobres podem ter no plantio de cana-de-açúcar para produção de etanol um eficiente instrumento para o desenvolvimento - Chávez tem pelo menos uma vantagem nesta disputa: a capacidade de dispor dos recursos do petróleo com mais rapidez. Se o Brasil tem a tecnologia para produção de combustíveis limpos, Chávez tem facilidade em mobilizar recursos econômicos e impulsionar projetos de integração que impressionam, como o já citado Gasoduto do Sul.

\section{3 - INTEGRAÇÃO FINANCEIRA}

A agenda de política externa de Chávez, porém, é mais ampla. Além da integração energética, o venezuelano encampou a integração financeira, com a criação do Banco do Sul em alternativa aos organismos financeiros internacionais, como o Banco Mundial e o FMI. A proposta, lançada sem mecanismos de consulta, deparou-se com a relutância do Brasil diante da rapidez com que Chávez tratou de implementar o novo organismo. O estilo chavista de política externa, vale dizer, concentra-se em laços políticos, deixando as questões técnicas para o segundo plano, como ocorrera com o Gasoduto do Sul. Entretanto, no caso do Banco do Sul, a pressa de Chávez prevaleceu. 
O descompasso entre Brasil e Venezuela não ficou restrito ao ritmo de criação, mas também à formatação e os objetivos do Banco do Sul. Em março de 2007, em um primeiro encontro, técnicos dos governos da Venezuela e Argentina definiram que o banco teria capital de US\$ 7 bilhões e sede em Caracas, contrariando a posição brasileira em defesa de uma cidade neutra para sediar a instituição (OPSA, n. 2, 2007).

Em reunião ampliada, no mês seguinte, os ministros da Economia e das Finanças de Argentina, Bolívia, Equador, Paraguai e Venezuela decidiram que o novo organismo financiaria projetos de infra-estrutura na região. Note-se que o governo brasileiro não participou deste encontro, justificando posteriormente a ausência de sua delegação. $O$ argumento - o convite apenas 48 horas antes do encontro inviabilizou a participação brasileira - foi interpretado como um sinal de que a proposta de criação do Banco do Sul não contava com o apoio do Brasil.

Em relação ao ritmo de criação, enquanto o governo venezuelano defendia a formalização do Banco do Sul ainda no primeiro semestre de 2007, o governo brasileiro defendia que um prazo de 120 dias fosse estabelecido para a conclusão de um esboço, mas não para definições fundamentais, como o plano de contas ou a formação do corpo técnico.

Em relação aos objetivos, o Brasil sustentava que os recursos deveriam financiar projetos de desenvolvimento, ao passo que, para Argentina e Venezuela, o Banco do Sul deveria ajudar seus sócios a protegerem-se contra crises financeiras e turbulências do mercado mundial.

Por último, em relação ao formato, a Venezuela propôs o depósito de parte das reservas internacionais dos países-sócios, operação não apenas rechaçada pelo Banco Central do Brasil, mas proibida pela Constituição brasileira. Ademais, a capitalização defendida pelo governo venezuelano também poderia provocar uma desaceleração da economia argentina, já que o governo seria obrigado por lei a retirar de circulação nacional três pesos para cada dólar retirado de suas reservas internacionais.

No que parece ser mais uma vitória política de Chávez do que um instrumento de integração regional, o Banco do Sul foi fundado em dezembro de 2007 sem uma estrutura definida. De acordo com a ata, o Banco do Sul financiará projetos destinados a incrementar a competitividade, e o desenvolvimento científico e tecnológico dos países membros Argentina, Bolívia, Brasil, Equador, Paraguai e Venezuela. Porém, a definição sobre o aporte de cada país para capitalizar a instituição, a composição da estrutura burocrática e os critérios para a escolha dos projetos ficaram para uma segunda fase. 
Em um esforço de síntese, duas barreiras encontram-se à frente do Banco do Sul: os países-membros são instáveis econômica e politicamente, tanto por suas condições internas como por sua vulnerabilidade externa; e, por outro lado, a maior parte do comércio exterior de cada nação não se dá com um membro da região, mas com terceiros. Essa característica reduz a possibilidade e até a conveniência de adaptação dos instrumentos de política econômica e social (Le Monde Diplomatique Brasil, 2008).

Sem dúvida, a iniciativa de criar o Banco do Sul significa um avanço em relação à subordinação financeira que dominou o subcontinente na década de 90 e reflete a mudança política na região, mas uma análise menos otimista sugere que o projeto corre o risco de cair na manipulação de governos ou setores políticos com propostas regionais conflitantes.

É fato, portanto, que, entre as esquerdas sul-americanas, há vasos comunicantes, apesar das discrepâncias entre moderados e radicais. Há, sem dúvida, fluxos de imitação e aprendizagem, contágio político, laços de solidariedade e linhas de cooperação, que podem prosperar. Mas há também jogos de interesse e passos de confrontação, parte da rivalidade entre modelos e da disputa pela liderança da América do Sul. 


\section{CONCLUSÃO}

A vasta dimensão territorial do Brasil, com seus extensivos recursos humanos e naturais, e o peso de sua economia deram ao país um nível de poder e influência que ultrapassa em muito o de outros países da América do Sul. De acordo com dados do Banco Mundial de 2006, o Brasil tem praticamente metade da população da região (188,9 milhões de habitantes), mais da metade do PIB (R\$ 2,5 trilhões) e metade da área (8,5 milhões de quilômetros quadrados), fazendo fronteira com nove países. Já a Venezuela tem cerca de 27 milhões de habitantes, representando apenas 9\% da população da América do Sul, pouco mais de 7\% do PIB regional e uma área de 916 mil quilômetros quadrados, que fazem fronteira com apenas dois países além do Brasil (BBC, 2008).

Seria um exagero, portanto, à primeira vista, sustentar que o ativismo do presidente Hugo Chávez represente uma real ameaça à liderança brasileira. Porém, o que deveria ser uma liderança incontestável passou a ser confrontada a partir da eleição de governos de esquerda, com suas diferentes tonalidades, na América do Sul. As controvérsias transformaram-se em uma disputa entre as duas correntes esquerdistas que governam 0 subcontinente. A moderada, liderada por Lula, leva vantagem, embora os radicais, seguidores de Chávez, demonstrem intensa capacidade de pôr à prova a estabilidade regional.

Chávez apresenta uma postura mais personalista se comparado a outras lideranças regionais (Coutinho, 2006). Se o ativismo é o mais tradicional e constante recurso de política externa da Venezuela, o uso político do petróleo é a segunda constante. No entanto, uma terceira constante incorpora um traço patrimonial da cultura política venezuelana: o personalismo. É certo que Chávez herdou uma tradição que concentra os poderes de decisão de política externa nas mãos do presidente da República. Mas também é certo que a agenda política interna e externa é definida hoje na Venezuela, em grande medida, em função das características políticas individuais do presidente da República e de suas idéias por vezes espontâneas e circunstanciais, ou seja, as metas da diplomacia venezuelana são definidas em função das crenças e interesses individuais da figura presidencial (Villa, 2007). Lula, por sua vez, mesmo gozando de grande apelo popular, governa fazendo mais um jogo institucional do que de mobilização social.

Assim, o papel de liderança e de estabilização que o Brasil procura desempenhar esbarra no ativismo da política externa da Venezuela para a América do Sul. Villa (2007) argumenta que este confronto tem contribuído para revisar idéias que se originaram no pensamento liberal no fim do século XIX, de que governos de países com 
regimes de natureza política parecida tendem a ser mais cooperativos entre si, e que governos com regimes de natureza diferente teriam relações mais conflitivas. O pensamento liberal da teoria das relações internacionais define isso como teoria da paz democrática que, resumidamente, afirmava, desde Kant, que governos democráticos não fazem guerra entre si. O autor sugere que esta premissa teórica seja torcida para que seja possível dizer que governos de regimes de esquerda tenderiam a ter relações mais cooperativas entre si.

Para Villa (2007), com a atual tendência de governos de esquerda emergindo na América do Sul, essa idéia fazia bastante sentido, e algumas metas estratégicas de países da região, como o processo de integração regional, achariam um contexto mais favorável. Essa foi uma aposta forte da política externa do Brasil inaugurada pelo governo de Lula em relação a governos nacionalistas - e com fortes tonalidades de esquerda - como o da Venezuela de Hugo Chávez. Mas não foi o que ocorreu.

O distanciamento entre as esquerdas inspiradas em Lula e Chávez deu-se, mais claramente, em torno da estratégia energética. Os países andinos, sobre os quais o venezuelano exerce forte influência, relutam em diversificar a matriz energética da região, comportamento justificado pela alta dependência dos recursos oriundos da exploração do gás e do petróleo. E, por isso, decidiram ampliar o controle do Estado sobre os recursos energéticos, com políticas de nacionalização. O Brasil, por outro lado, apresentou aos fóruns mundiais sua aposta em uma matriz energética renovável, com a produção do etanol, capaz de levar desenvolvimento aos países pobres da América Central e Caribe.

Villa (2007) considera que, se Chávez seguir adiante em suas iniciativas, no curto prazo, as possibilidades brasileiras de neutralizar a Venezuela (e manter a estabilidade regional) já não serão amplas, por sua flexibilidade para usar ou disponibilizar rapidamente recursos econômicos e ampliar sua influência política. Porém, com recursos políticos de menos e com recursos econômicos de sobra, a liderança venezuelana tem agido com pouca visão estratégica do que deve ser o exercício de convivência e de mecanismos de consultas com seus vizinhos sul-americanos.

Para Cervo (2001), a Venezuela continuará vivendo de sonho e de ilusão: o sonho bolivariano e a ilusão do petróleo. O primeiro não deverá lhe garantir a pretendida liderança sobre a América do Sul, e a segunda não trará o desenvolvimento social e econômico esperado.

Seria apressado, portanto, supor que as contradições de conceito e de estilo possam produzir uma fratura entre as esquerdas que governam a América do Sul. Possivelmente, para Lula, receber Hugo Chávez e Fidel Castro com honras, dar-lhes um trato 
cordial, abrir as portas de suas massas populares, considerá-los parte da família, é uma forma de lealdade com a própria história (Petkoff, 2005). Não significa subordinação, tampouco condescendência. Acordos e bom entendimento entre Brasil e Venezuela, moderados e radicais, devem ser aplaudidos por todos que vêem a integração regional como espaço de autonomia e afirmação da identidade sul-americana, o que só contribui para a construção de um mundo multipolar, integrado, justo e solidário. Contudo, este trabalho conclui que, ao Brasil, será sempre confiado o papel de líder da América do Sul. De que forma esta liderança se dará, a História dirá. 


\section{BIBLIOGRAFIA}

ALEXANDRE, Cristina e PINHEIRO, Flávio Leão. Integração energética sul-americana, Artigos e Conferências OPSA, jul. 2005, disponível em http://observatorio.iuperj.br/pdfs/25_artigos_artigo_jb_cristina_e_flavio.pdf.

ALMEIDA, Paulo Roberto. Uma política externa engajada: a diplomacia do governo Lula. Revista Brasileira de Política Internacional, São Paulo, v. 47, p. 162-184, 2004.

BANDEIRA, Luiz Alberto Moniz. O Brasil e a América do Sul. In: ALTAMANI, Henrique e LESSA, Antônio Carlos (Org.). Relações Internacionais do Brasil: temas e agendas, v.1. São Paulo: Saraiva, 2006. p. 267-297.

CERVO, Amado Luiz. A Venezuela e seus vizinhos. Revista Cena Internacional, São Paulo, n. 2, p. 7-10, 2001.

A política exterior: de Cardoso a Lula. Revista Brasileira de Política Internacional, São Paulo, v. 44, p. 5-11, 2004.

COUTINHO, Marcelo. Popular, populistas e neoliberais, Artigos e Conferências OPSA, mai. 2006a, disponível em http://observatorio.iuperj.br/pdfs/61_artigos_Popular_Populistas_e_Neoliberais.pdf.

. Movimentos de mudança política na América do Sul contemporânea. Revista de Sociologia Política, Curitiba, v. 27, p. 107-123, nov. 2006b.

. Novos Ventos do Sul: um breve ensaio de econômica política contemporânea, Análise de Conjuntura OPSA, n.1, jan. 2007, disponível em http://observatorio.iuperj.br/artigos_resenhas/Novos_ventos_do_sul.pdf.

GONÇALVES, José Botafogo e LYRIO, Maurício Carvalho. Aliança e estratégia entre Brasil e Argentina: antecedentes, estado atual e perspectivas. Dossiê, São Paulo, v. 2. p. 5-25, 2003.

HIRST, Mônica. Os cinco “As” das relações Brasil - Estados Unidos: aliança, alinhamento, autonomia, ajustamento e afirmação. In: ALTAMANI, Henrique e LESSA, Antônio Carlos (Org.). Relações Internacionais do Brasil: temas e agendas, v.1. São Paulo: Saraiva, 2006. p. 91-127. 
LIMA, Maria Regina Soares e COUTINHO, Marcelo Vasconcelos. Integração Moderna, Análise de Conjuntura OPSA, n. 1, jan. 2006, disponível em http://observatorio.iuperj.br/pdfs/25_artigos_artigo_jb_cristina_e_flavio.pdf.

LLANA, Carlos Pérez. Argentina: o balanço da gestão Kirchner. Política Externa, São Paulo, v. 16, n. 2, p. 25-36, set-nov. 2007.

MAIOR, Luiz A. P. Souto. Desafios de uma política externa assertiva. Revista Brasileira de Política Internacional, São Paulo, v. 46, p. 12-34, 2003.

MIRELES, Pedro David montes. Mito y realidad de la ola chavista: amenaza para la región o provocación ideológica?, Artigos e Conferências OPSA, out. 2006, disponível em http://observatorio.iuperj.br/pdfs/73_artigos_Mito\%20y\%20realidad\%20de\%20la\%20ola\%20 chavista.pdf.

NETO, Octavio Amorim. A política externa brasileira: novos dilemas geopolíticos e sua falta de condiconamentos domésticos Análise de Conjuntura OPSA, n.3, mar. 2007, disponível em http://observatorio.iuperj.br/pdfs/30_analises_AC_n_3_mar_2007.pdf.

ONUKI, Janina. O Brasil e a construção do Mercosul. In: ALTAMANI, Henrique e LESSA, Antônio Carlos (Org.). Relações Internacionais do Brasil: temas e agendas, v.1. São Paulo: Saraiva, 2006. p. 299-320.

PANIZZA, Francisco. La marea rosa, Análise de Conjuntura OPSA, n.8, ago. 2006, disponível em http://observatorio.iuperj.br/pdfs/21_analises_La_marea_rosa.pdf.

PETKOFF, Teodoro. Las dos izquierdas. Nueva Sociedad, Buenos Aires, n.197, p. 114-128, 2005.

SANTANA, Carlos Henrique e KASAHARA, Yuri. Algo de novo no front? O retorno do Estado e seus impactos para a integração sul-americana, Observador On-Line OPSA, v. 2. n. 4 abril. 2007, disponível

http://observatorio.iuperj.br/pdfs/17_observador_topico_Observador_v_2_n_4.pdf.

SANTOS, Maria Helena de Castro. Que Democracia? Uma visão conceitual desde a perspectiva dos países em desenvolvimento. Revista de Ciências Sociais, Rio de Janeiro, v. 44, n. 4, p. 729 a 771, 2001.

TOKATLIAN, Juan Gabriel. Un neo anti-brasileanismo?, Artigos e Conferências OPSA, set. 2004, disponível em Mireles, Pedro David montes. Mito y realidad de la ola chavista: 
amenaza para la región o provocación ideológica?, Artigos e Conferências OPSA, out. 2006, disponível em http://observatorio.iuperj.br/pdfs/73_artigos_Mito\%20y\%20realidad\%20de\%20la\%20ola\%20 chavista.pdf.

TURNER, Frederick C. Hegemonia e o caso do Brasil. Contexto Internacional, Rio de Janeiro, v. 13, n.1, p. 53-80, jan-jun. 1991.

VALENTE, Leonardo e SANTORO, Maurício. A diplomacia midiática do governo Hugo Chávez, Artigos e Conferências OPSA, abr. 2006 disponível em http://observatorio.iuperj.br/pdfs/56_artigos_Diplomacia_Midiatica_Governo_Chavez.pdf.

VILLA, Rafael Duarte. Limites do ativismo venezuelano para América do Sul. Política Externa, São Paulo, v. 16, n. 2, p. 37-49, set-nov. 2007.

VIZENTINI, Paulo Fagundes. O G-3 e o G-20: O Brasil e as novas coalizões internacionais. In: ALTAMANI, Henrique e LESSA, Antônio Carlos (Org.). Relações Internacionais do Brasil: temas e agendas, v.2. São Paulo: Saraiva, 2006. p. 159-193.

JORNAIS E REVISTAS

BANCO DO SUL: libertação ou ilusão? Le Monde Diplomatique Brasil, São Paulo, n.8, mar. 2008.

O ENIGMÁTICO HUGO CHÁVEZ. Le Monde Diplomatique Brasil, São Paulo, n. 7, ago. 2000.

PANTONÍMIA. O Globo, Rio de Janeiro, set. 2006

VENEZUELA E IRÃ LUCRAM COM ELO IDEOLÓGICO. Folha de São Paulo, 5 ago 2007.

SITES

BBC BRASIL. Para analistas, Chávez ocupa espaços, mas não ameaça Brasil. Disponível em: www.bbc.co.uk/portuguese. Acesso em 13 mar 2008. 
FREEDOM HOUSE. Freedom in the world. Disponível em: www.freedomhouse.org. Acesso em 7 fev 2008.

MINISTÉRIO DAS RELAÇÕES EXTERIORES. Discursos, artigos, entrevistas e outras comunicações. Brasília, 2003. Disponível em: www.mre.gov.br. Acesso em: 10 mar 2008.

OBSERVATÓRIO POLÍTICO SUL-AMERICANO. Boletim OPSA n. 1, jan-fev. 2006. Rio de Janeiro, 2006. Disponível em: http://observatorio.iuperj.br/. Acesso em 7 fev 2008.

. Boletim OPSA n. 2, mar. 2006. Rio de Janeiro, 2006. Disponível em: http://observatorio.iuperj.br/. Acesso em 7 fev 2008.

. Boletim OPSA n. 4, mai. 2006. Rio de Janeiro, 2006. Disponível em: http://observatorio.iuperj.br/. Acesso em 7 fev 2008.

Boletim OPSA n. 5, jun. 2006. Rio de Janeiro, 2006. Disponível em: http://observatorio.iuperj.br/. Acesso em 7 fev 2008.

. Boletim OPSA n. 7, set. 2006. Rio de Janeiro, 2006. Disponível em: http://observatorio.iuperj.br/. Acesso em 7 fev 2008.

Boletim OPSA n. 1, jan-fev. 2007. Rio de Janeiro, 2006. Disponível em: http://observatorio.iuperj.br/. Acesso em 7 fev 2008.

. Boletim OPSA n. 2, mar-abr. 2007b. Rio de Janeiro, 2006. Disponível em: http://observatorio.iuperj.br/. Acesso em 7 fev 2008.

. Boletim OPSA n. 4, jul-ago. 2007. Rio de Janeiro, 2006. Disponível em: http://observatorio.iuperj.br/. Acesso em 7 fev 2008.

Boletim OPSA n.6 , nov-dez. 2007. Rio de Janeiro, 2006. Disponível em: http://observatorio.iuperj.br/. Acesso em 7 fev 2008.

PRESIDÊNCIA DA REPÚBLICA. Discursos e entrevistas. Brasília, 2003. Disponível em: www.info.planalto.gov.br. Acesso em: 10 março 2008. 